\title{
IAMJ
}

INTERNATIONAL

AYURVEDIC

MEDICAL JOURNAL

Review Article

ISSN: 2320-5091

Impact Factor: 6.719

\section{REVIEW OF CHARAKOKTA SUTIKA PARICHARYA AND ITS CLINICAL SIGNIFICANCE}

\section{Komal Gurjar $^{1}$, B. Pushpalatha ${ }^{2}$, K. Bharathi ${ }^{3}$, Poonam Choudhary ${ }^{4}$}

${ }^{1}$ Final Year M.S. Scholar, Department of Prasuti Tantra and Stree-Roga, National Institute of Ayurveda, Jaipur, India

${ }^{2}$ Associate Professor, Department of Prasuti Tantra and Stree-Roga, National Institute of Ayurveda, Jaipur. Ph.D Scholar, Tilak Maharashtra Vidyapeeth, Pune, Maharashtra,

${ }^{3}$ HOD and Professor, Department of Prasuti Tantra and Stree-Roga, National Institute of Ayurveda, Jaipur, India ${ }^{4}$ lecturer, Department of Prasuti Tantra and Stree-Roga, National Institute of Ayurveda, Jaipur, India

\section{Corresponding Author:gurjarkomal427@gmail.com}

\section{https://doi.org/10.46607/iamj4009092021}

(Published Online: September 2021)

Open Access

(C) International Ayurvedic Medical Journal, India 2021

Article Received:25/08//2021 - Peer Reviewed:04/09/2021 - Accepted for Publication:05/09/2021

\section{Check for updates}

\section{ABSTRACT}

The transformation of a female, from a woman to a mother is the happiest lifetime event, but this happiness is gained only after undergoing tremendous physical exertion during labour. The women become extremely debilitated physically \& mentally, after the delivery \& there are more incidences of backache, feeling weakness etc. After the delivery of the baby, the placenta is expelled then the woman is termed as Sutika \& the care is termed as Sutika-Paricharya. Mithyaachara during this period results in incurable diseases or diseases which are difficult to cure. After following proper Sutikopacharya (puerperal regimen) woman regains all the lost things and reaches pre-pregnancy status. The mode of Paricharya includes important therapies, nutritional diet \&Swasthavrithapalana. The main achievements through Sutika-Paricharya are Garbhashayashuddhi, DhatuParipurnata, Sthanya-Vriddhi,Punarnavekarana. So, the present study has been selected to review CharakoktaSutika-Paricharya\& its clinical importance.

Keywords: Sutika, SutikaParicharya, SutikaParicharya, Mithyaachara 


\section{INTRODUCTION}

Motherhood is all about loving, sharing, sacrificing, and struggling. Ayurveda emphasizes much importance of the care of women, especially in the prenatal and postnatal periods. The sound 'puthramsuthe' brings back jeeva i.e. life to a parturient woman. But this is possible if her health is taken care of during postnatal. mild derangement can cause lifethreatening situations for mother and baby. Hence extreme care is to be taken during pregnancy and puerperium. The postnatal period begins immediately after the separation of the placenta and extending up to six weeks (this period varies as some Acharyas described up to 45days or up to 6 months after delivery), otherwise called Puerperium or Puerperal period.

During the time of labour, the mother undergoes tremendous physical exertion and becomes extremely debilitated physically and mentally, which leads to derangement of Doshas especially Vatadosha in the mother. These pathological changes cause general weakness, pain abdomen, low back pain, loss of appetite, dysfunction of the bladder, post-natal psychosis etc. Apart from these, the mother also suffers from Dhatukshya. If this stage is unattended by appropriate measures, then that will lead to maternal morbidity. To reduce postpartum maternal morbidity, reforming postpartum care measures by providing holistic and flexible maternal health care is necessary. The WHO suggested that maternal care should be demedicalized, individualized, family-centred, multidisciplinary, holistic, and culturally appropriated. In the existing modern medical system, puerperal care limits to supplementation of iron, calcium and prevention of infections. Two major demands of Puerperium i.e. care for proper involution of genital organs and ensuring optimum lactation are still left un- addressed. Whereas in Ayurveda medicaments and procedures described for a post-natal woman is culturally very much appropriate, is by and large comprehensive in serving all the demands of the puerperium. It is by far more scientific and helps in proper involution of the uterus, ensures optimum lactation, kindles digestive as well as metabolic fire, replenishes the lost Dhatu (tissue elements), prevents infections, helps to regain tone of the urinary bladder and other smooth muscle organs like the intestine, finally it ensures the uneventful puerperium and complete growth of the body. Keeping in view the above facts there is a need to evolve holistic treatment modalities which could be effective, safe, accessible, without any side effects. Ayurvedic texts provide various effective treatments for Sutika. These Ayurvedic Sutika Paricharya (as per Acharya Charaka) has been in use for ages and is useful in treating Sutika (post-natal women) and promoting health.

AIM AND OBJECTIVES - To review the literature of Sutika, Sutikakala, with Clinical significance of Charkokta Sutika Paricharya ${ }^{1}$.

MATERIAL AND METHODS- This is a review study. Textual materials are used for the study from which various references have been collected. The main Ayurvedic texts used in this study are Charak Samhita, Sushruta Samhita, Ashtang-Sangraha, Kashyap Samhita. Commentaries are also included in it.

\section{SUTIKA}

1. Definition - A woman who has just given birth to a child followed by the expulsion of the placenta is called Sutika by Acharya Kashyapa ${ }^{2}$ The care given during this period is called Sutika Paricharya in Ayurveda.

2. Sutika Kala (duration of postnatal phase)

Table 1: Sutika kala (Time period) according to different Acharyas/Samhita

\begin{tabular}{|l|l|}
\hline Literature & Period \\
\hline Charak Samhita & Not specified ${ }^{3}$ \\
\hline Sushruta Samhita & $1^{1 / 2}$ month or until next Rajodarshan ${ }^{4}$ \\
\hline Ashtanga Sangraha & One and half months or until the next Rajodarshan $^{5}$ \\
\hline Ashtanga Hridya & One and half months or until the next Rajodarshan \\
\hline
\end{tabular}




\begin{tabular}{|c|c|}
\hline Bhavprakash & $\begin{array}{l}\text { In addition, agreeing explanation of Sushruta (i.e. } 1 \frac{1 / 2}{2} \text { month), he has cited that following subsid- } \\
\text { ence of complication and aggravation of Doshas, the woman should give unspecific mode of } \\
\text { life following four months }{ }^{7} \text {. }\end{array}$ \\
\hline Yogratanakar & Special dietetic management for 1 month $^{8}$ \\
\hline Kashyapa & Sixth months ${ }^{9}$ \\
\hline
\end{tabular}

3. SUTIKA PARICHARYA: A care of the woman during puerperium comes under the heading of Sutika Paricharya. Its principles are given as follows:

* Agnideepan,

* Pachana,

* Raktavardhaka,

\author{
* Stanyavardhaka, \\ * Yonisanrakshaka, \\ * Garbhashayashodhaka \\ * Kostashodaka, \\ * Dhatupusti, \\ * Balya.
}

Table 2: Sutika Samanya Paricharya according to Acharya Charaka ${ }^{10}$

\begin{tabular}{|c|c|c|}
\hline Number of days & Ahara & Vihara \\
\hline Upto $5-7$ days & $\begin{array}{l}\text { Snehapana and Yavagupana which is medicated with } \\
\text { Pippali (piper longum), Pippalimoola (piper longum's } \\
\text { root), Chavya (piper retrofractum), Chitraka (plumba- } \\
\text { go zeylanica), Shunthi (zinziber officinale) for 5-7 days } \\
\text { after delivery. Anupana - Ushna Jala. Use of Brihaga- } \\
\text { na drugs from 6th or 8th day. }\end{array}$ & $\begin{array}{l}\text { Abhyanga of the abdomen with taila } \\
\text { or Ghrita. Udarveshtana with a big } \\
\text { clean cloth. Parisheka (Irrigation) } \\
\text { with lukewarm water. }\end{array}$ \\
\hline $8^{\text {th }}-11^{\text {th }}$ day & Apyayana and Swasthvritta Palana & \\
\hline
\end{tabular}

According to Acharya Charaka, when a puerperal woman feels hunger, she should be given powdered Pippali, Pippalimoola, Chavya, Chitrak, and Sringvera, along with one of Ghrita, oil, Vasa (animal fat), or Majja (marrow), in a quantity that she can easily digest. Her abdomen should be massaged and covered appropriately with a large clean cloth after she has consumed this. This wrapping compresses the abdomen, preventing the existence of hollow space and thereby preventing the Vayu from being vitiated. Following the digestion of Ghrita, etc. Fats, ricebased liquid gruel medicated with Pippali etc., as well as the drugs listed above mixed with Ghrita, should be given. Irrigation or a hot water bath should be done before using Ghrita or gruel at all times, morning and evening. According to Chakrapani, irrigation should be provided in the morning before ingestion of oleaginous substances and repeated after digestion, followed by rice gruel. Gradual administration of Vrnghana substance (anabolic or likely to increase flesh and energy) should be performed after using this regimen for five or seven nights (days and nights). Because the Kapha is dominant in the people of Anupadesha (marshy land), this regimen is not appropriate for them. This regimen is appropriate for Jangala (wild or dry) women 
Table 3: Pharmacodynamic properties of drugs used in Charakokta Sutika Paricharya ${ }^{11}$ - Pippalyadi Churna -

\begin{tabular}{|l|l|l|l|l|l|l|l|}
\hline Name & Part use & Ratio & Rasa & Guna & Virya & Vipaka & Doshaghanta \\
\hline $\begin{array}{l}\text { Pippali(Piper longum } \\
\text { Linn.) }\end{array}$ & Fruits & 1 & Katu & $\begin{array}{l}\text { Lagu, Snigdha, } \\
\text { Tikshna }\end{array}$ & $\begin{array}{l}\text { Anushna } \\
\text { Sheeta }\end{array}$ & Madhura & Kaphavatashamaka \\
$\begin{array}{l}\text { Pippalimoola (Piper } \\
\text { longum Linn.) }\end{array}$ & Root & 1 & Katu & $\begin{array}{l}\text { Laghu, Rooksha } \\
\text { Ushna }\end{array}$ & Katu & Vaphavatashamaka \\
\hline $\begin{array}{l}\text { Chavya (Piper chaba } \\
\text { Hunter) }\end{array}$ & Fruit & 1 & Katu & Laghu, Rooksha & Ushna & Katu & Vatakaphashamaka \\
\hline $\begin{array}{l}\text { Chitrka(Plumbegozelenica } \\
\text { Linn.) }\end{array}$ & Root & 1 & Katu & $\begin{array}{l}\text { Laghu, Rooksha, } \\
\text { Teekshna, }\end{array}$ & Ushna & Katu & Vatakaphashamaka \\
$\begin{array}{l}\text { Nagar (Zingiber offici- } \\
\text { nalsRoxb.) }\end{array}$ & Rhizome & 1 & Katu & $\begin{array}{l}\text { Laghu, Snigdha, } \\
\text { Lalsha }\end{array}$ & Madhura & Vatakaphashamaka \\
\hline
\end{tabular}

\begin{tabular}{|l|l|l|l|l|l|}
\hline Name & Rasa & Guna & Virya & Vipaka & Doshaghanta \\
\hline VidarikandaChurna & Madhura & Guru, Snigdha, & Sheeta, & Madhura & Vatapitta Shamak \\
\hline Go-Ghrita & Madhura & Snigdha,Mridu, Shalakshana & Sitta & Madhura & Ttridosha Shamaka \\
\hline Tila taila & Madhura & Suksma, Guru, Sara, & Ushna & Madhura & Alleviates Tridosha \\
\hline
\end{tabular}

\section{* CLINICAL SIGNIFICANCE OF CHRAKOK-} TA SUTIKA PARICHARYA

1. Pippalyadi Churna - Pippalayadi Churna (Pippali, Pippalimoola, Chavya, Chitraka, Shrungavera) is having property of Agnideepana, Amapachana and Vatashamak. These dravyas help in the digestion of Sneha and serve as an appetizer. Pippali, Pippalimula, Chavya, Chitraka, Shringavera are Ushna, Teekshna, Deepana, Pachana, Shoolagna \& Kaphavatashamaka. These drugs are katu Rasatmaka and Katu vipaki and have Shonita SanghatBhedana properties, which trigger normal Yoni Gatasrava and Garbhashaya Shudhi.

$\diamond$ Pippali (Piper longum) \& Pippalimool (Piper longum)-Rejuvenating, stimulant, expectorant, emollient, carminative, aphrodisiac, warming, and decongestant are some of the properties of Pippali. Pippali and Pippalimula have anti-inflammatory and antibacterial properties. It's also good for regaining control of the relaxed organs after delivery.

$\diamond$ Chavya (Piper chaba Hunter) -The fruits of this Piper species are stimulants, anti-catarrhal, and carminative. Chavya stimulates the liver and cleanses the blood, as well as having rejuvenating properties.
Chitraka (Plumabago zeylenica): - Increases appetite and helps indigestion. Dyspepsia, piles, and skin disorders are all treated with this herb. Chitraka can be used as an appetizer, digestive aid, anti-helminthic, and uterine contraction stimulant and cures postpartum disorders.

$\diamond$ Sunthi (Zingiber officinale): -Sunthi is having the property of Stimulating, diaphoretic, expectorant, carminative. Sunthi is a tasty spice that is used in Ayurvedic medicine to aid digestion and avoid nausea. The digestive system is regulated by these properties for assisting bowel movements and calming muscles. In many Ayurvedic formulations, Sunthi is used as an adjuvant to improve absorption and prevent gastrointestinal side effects. It is anti-inflammatory and antimicrobial.

$\diamond$ Go-Ghrita as Sahapana - Ghrita has one property i.e. Samskaranuvartana. It can imbibe the qualities of components without losing its natural properties, which is known as Samskaranuvartan. Because it is Yogavahi, it contains active ingredients from medications to boost the strength of compound drugs. Pippalyadi Churna was given with the Sahapana of ghrita, which added Rasayana properties to the formulations while also lowering Tikshna Guna. It contains Agnivardhaka, Rocha$k a$, Ojovardhaka, and Vrishya qualities, which 
serve to control Tridoshas and aid in correct Dhatus and Updhatus development. Ghrita provides many essential fatty acids such as omega 6 which provides anti-inflammatory properties. It contains 3\% linoleic acid, an antioxidant. It also contains vitamins A, D, E, K. Pippalyadi Churna
(Pippali, Pippalimoola, Chavya, Chitraka, Shunthi) with Ghrita have antipyretic, appetizer, uterotonic, antibacterial, antifungal, and act as analgesic effect That's why the Pippalyadi Churna with Ghrita is used to improve digestive power and Vata PrakopakaVikara in Sutika

1. Flow chart - Mode of Action of Pippalyadi Churna Sidha Ghrita Pana ${ }^{12}$

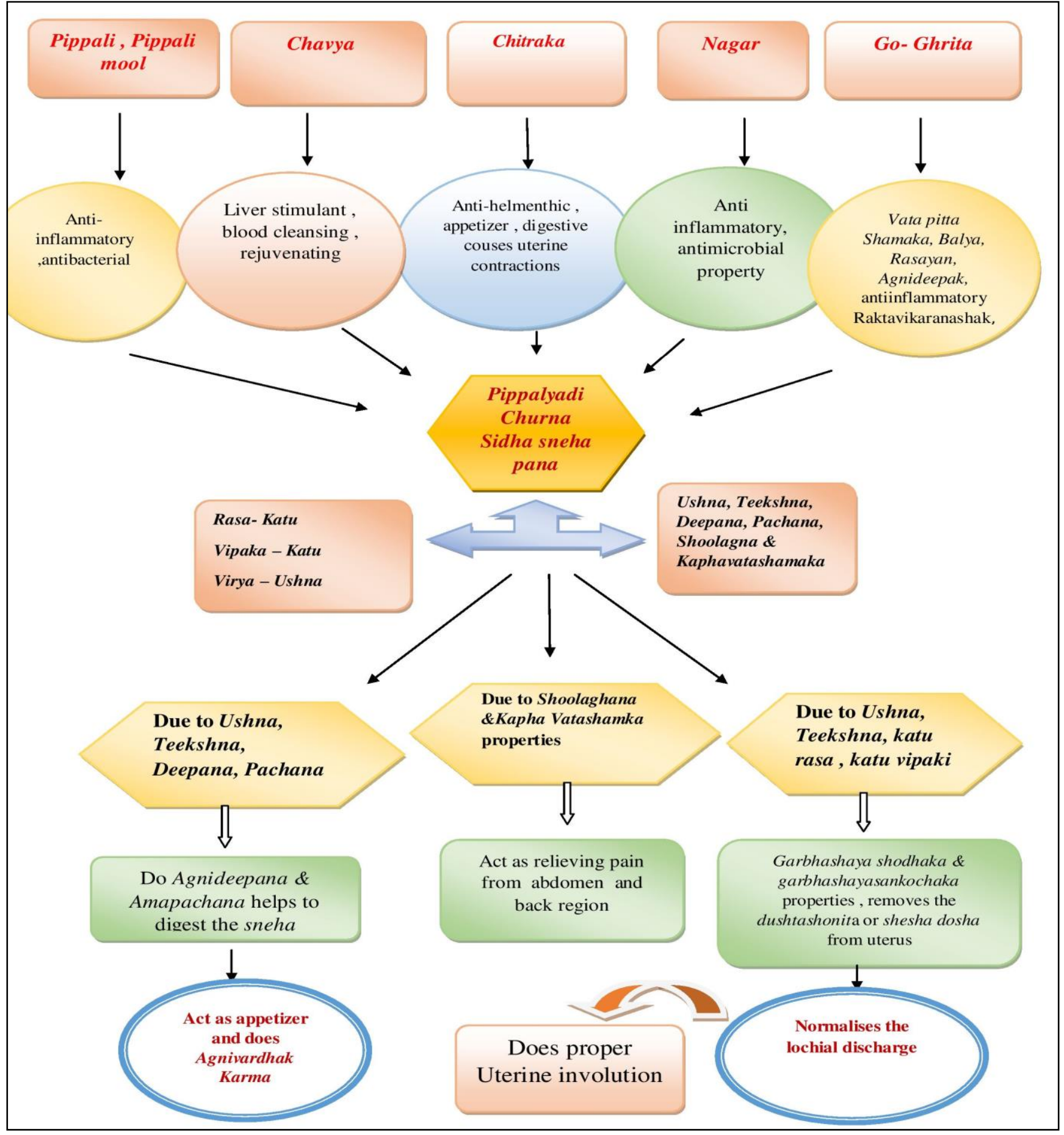


2.Abhyanga - Abhyanga on Udara, Kati, Pristha, Parshva with the help of Tila Taila which is Brimhana, Tvak Prasadana, Sthairya Balavarnakara, Yoni ShoolaPrashamana, GarbhashyaShodhana. Pressure points are included in Abhyanga, and they are strikingly like the anatomical location of lymph nodes. This technique aims to increase lymph flow in the skin as well as lymph movement in the body's larger lymphatic vessels and lymph nodes. Lymph includes many lymphocytes, which are responsible for preserving the body's immunological tolerance in the circulatory system via vasodilation. Abhyanga increases blood flow in the local region. This allows more leucocytes and macrophages to enter the damaged tissue, speeding up wound healing. Vasodilation reduces inflammation when the intravascular compartment's pressure drops, and fluid from the extravascular compartment travels to the intravascular compartment through a pressure gradient, where it flows out of the area via the bloodstream. Tension on nerve endings is relieved when inflammation is reduced, and pain is reduced.

\section{Flow chart - Mode of Action of Abhyanga with TilaTaila}

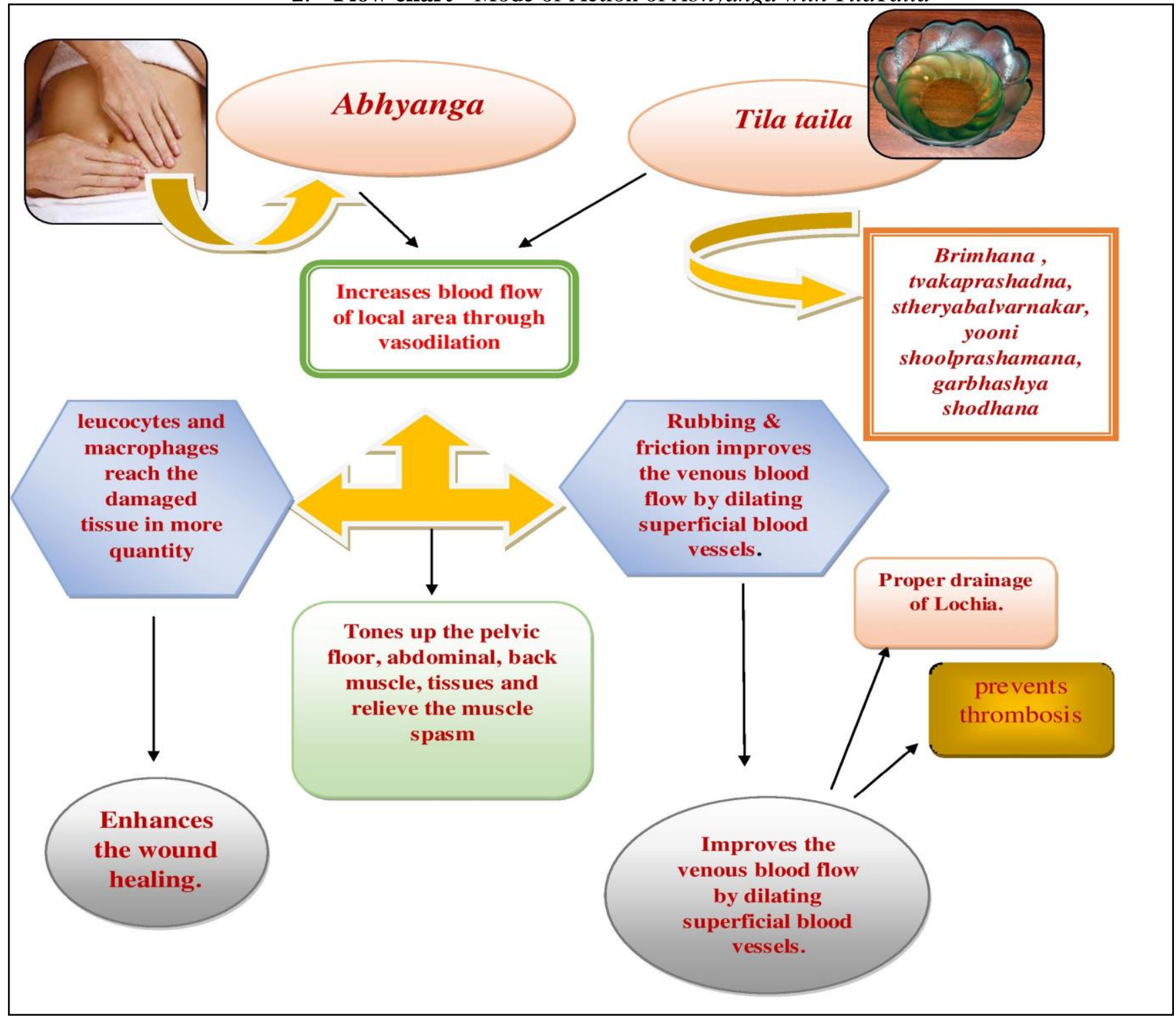


4. Udarapattabandhana - Wrapping the abdomen with a long and clean cotton cloth helps the abdomen return to its natural position and prevents vata accumulation in vacant areas. It prevents Vatadosha vitiation by compressing the hollow space left after the foetus is expelled. It supports the back and the abdomen. It primarily helps the uterus return to normal size.

\section{Flow chart- Mode of Action of UdaraPattabandana ${ }^{13}$}

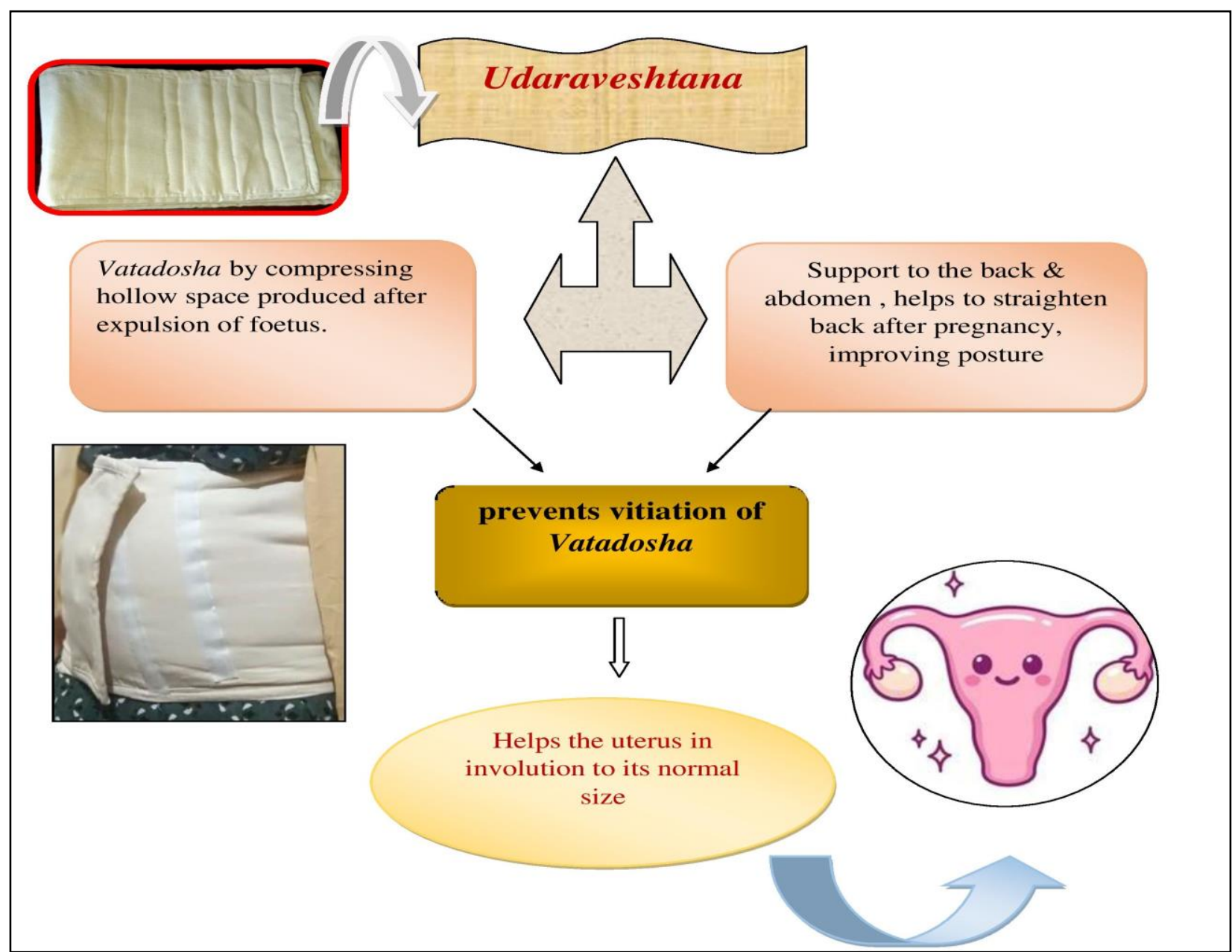

\section{Pippalyadi Churna Sidha Sneha Yavagu Pana -} Yavagu is an easy-to-digest Pathya Kalpana that can be used in Sutika with low digestive capacity, such as Agnimandya. Yavagu is used as a mediator to administer medications to patients who are having low digestive capacity. It not only improves digestive capacity but can also be used as medicine. Yavagu is more convenient than any other food since it is easy to cook and digest. The Pippalyadi Samyoga with Yavagu boosted its effectiveness even further. Among the Paradi Guna, Samyoga Guna is extreme- ly significant. According to Acharya Charaka, the Samyoga is the main cause of all Karma (Chikitsa). As a result of the Pippalyadi Samyoga with the $\mathrm{Ya}$ vagu, the efficacy is enhanced. This is one of the reasons for the current study's better results. Pippalyadi Churna is having Katu Rasa dominancy, which is Agnidipana Rasa. Katu is the Vipaka of Pippalyadi churna $^{14}$. Because the rasa of dravya is the same as Vipaka, Karya may occur by the Rasa i.e. Agnidipana $^{15}$ Since it also has an impact on the Jarana Shakti. The Vishamagni and Mandagni both are im- 
proved with this Pippalyadi churna Siddha Yavagu. The impact on the Mandagni is shown by Katu Rasa,Katu Vipaka and Ushna Virya i.e. by the entire aspect of the drug. It can work in Vishamagni through the Ushna Virya of drug and vatanulomana property of Yavagu.

6. Vidarikanda Churna With Cow Milk ${ }^{16}$ - The mode of action of Vidarikanda Churna to increase breast milk has the same qualities as Stanya, which is up- dhatu of Rasa dhatu. Guru, Sheeta, Snigdha, Madhura Vipaki, and Sheeta Veerya are all terms used to describe Madhura rasa. With its guru, snigdha guna, it acts as Vatapita Shamaka. With guru, sheet, and snigdha guna, it serves as a pittashamaka. It's saptadhatuvardhaka, balyakara, and brimhana. It's dhatuposhaka and dhatushodhaka, thus it's good for dhatukshinata. As a result, the quality and amount of stanya improve.

4. Flow chart -Mode of Action of Vidarikanda Churna with Milk ${ }^{17}$ -

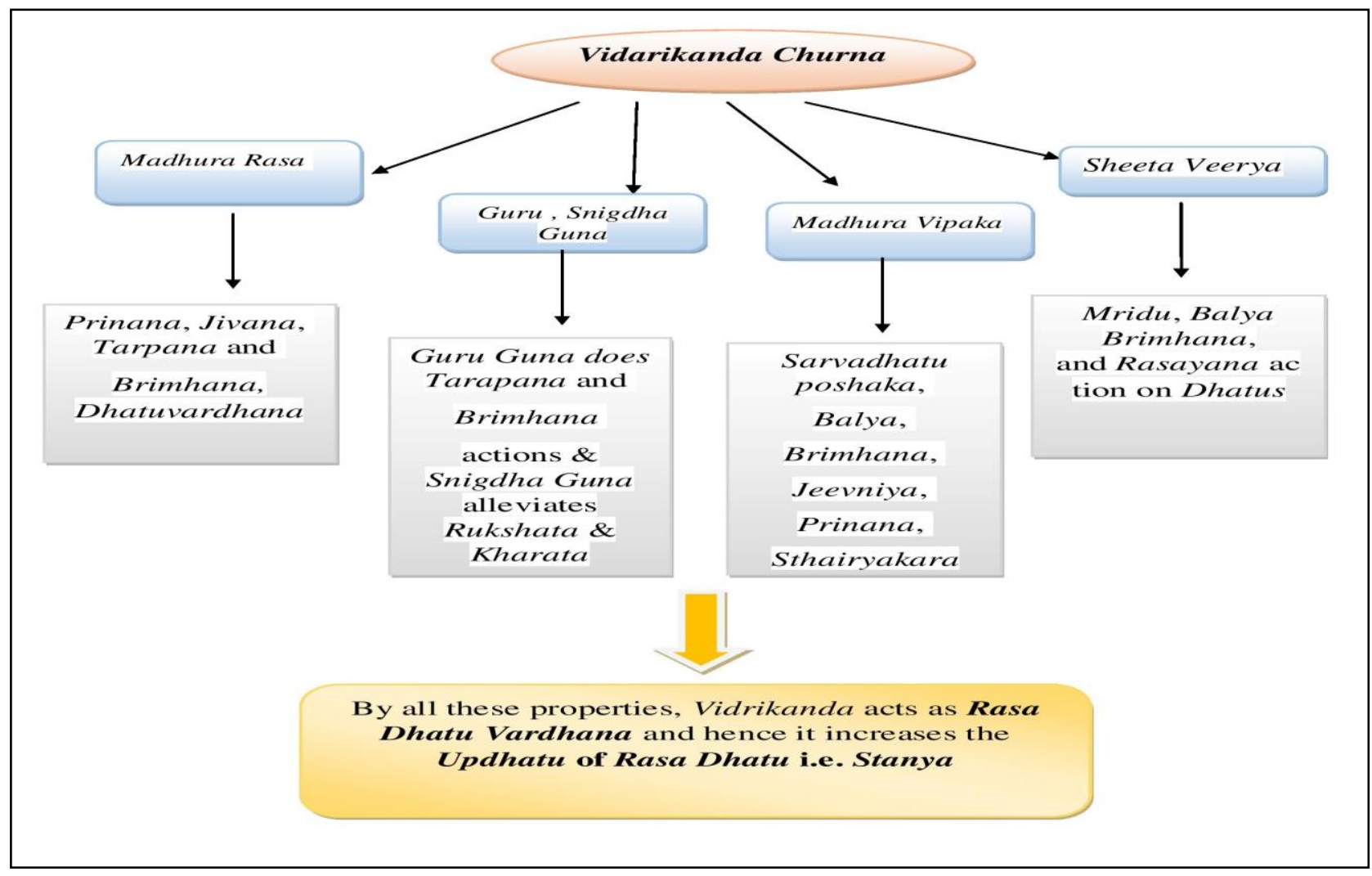

7. Parisheka ${ }^{18}$ : Parisheka is pouring hot water in a stream, it is vatakaphahara, vedanahara, does Agnideepti, Twakaprasannata, Srotoniramalata, so that abnormal blood clots accumulated in the uterine cavity after the delivery of Garbha excreted properly and Vata Dosha also subsides.

\section{DISCUSSION}

The woman become weak \& emaciated due to the growth of the foetus \& also an empty body due to the instability of all Dhatus, labour pains, excretion of
Kleda \& Rakta. By Paricharya she attains all the lost things and reaches her pre-pregnant state. Concept of Dhatu paripinnate (regaining her strength), Stanya utpatti (production of breast milk), Stanya Sampat (fullness of breast), Garbhashaya shuddhi, prevention of complications, and Punarnaveekaran (rejuvenation) is also attained.

\section{CONCLUSION}

SutikaParicharya restores the overall health of the Sutika and improves the quality of the progeny too. 
Nowadays, many complications arise in the condition of puerperal and are due to the imbalance in the mental status and improper knowledge regarding nutrition. These conditions affect the overall health of a lady. Most of the medicines preferred for Sutikaparicharya have antioxidant properties, prevent many diseases like hypertension, CNS (Central Nervous System) disorders, cancers, menstrual abnormalities, gastric disorders, etc. Effective Sutika Paricharya can conquer the misfortune or evil deeds of the preceding life. Sadvritta and Achara Rasayana are the two important pillars of the therapy and if used appropriately along with the main therapy, it will enhance the potency of the chief drug, ultimately restore the health along with eradication of the present illness (Cha. Chi.1-4th Pada/35). Nastika bhava (having negative thoughts) and other causes should be avoided and this procedure if followed according to the classics will be successful. Thus, different procedures are followed including Ahara and Achara for Punarnaveekarana of the Sutika is Sutika paricharya. It is the process of rejuvenation for the protection of Suti$k a$ and her child.

\section{REFERENCES}

1. Prof. P.V. Tiwari, Kashyapa Samhita text with English translation \& Commentary, pub Chaukambha Bharati Academy, Varanasi, edi-2002; 576.

2. Kashyapa Samhita Of Vriddha Jeevaka, Satyapala Bhigacharya, Varanasi, pub-Chaukhambha Sanskrit Sansthan, edi1994, Khilasthana chapter 10, 4th edition; p.181

3. Charaka Samhita, of Agnivesha, revised by Charaka Acharya, Yadavaji Trikamaji Chaukhambha Orientalia,5th edition, 2001; p.348

4. Ambikadutta shastri (editor). Sushruta Samhita, sharirasthana, chap-10, Bharati ChaukhambhaSubharti Prakashana, Varanasi 2010; p.103.

5. Premvati Tiwari, Ayurvediya Prasuti Tantra evamStriroga,part 2, chap-9, 2nd ed., Chaukhambha Orientalia, Varanasi. 1996; p.569

6. Premvati Tiwari, AyurvediyaPrasuti Tantra evamStriroga,part 2, chap-9, 2nd ed., Chaukhambha Orientalia, Varanasi. 1996; p.569

7. Purushottamnanal, editor, Sartha Bhavaprakash, PurvaKhanda, chap-3, 1st ed. Shri Gajanana Book Depo, Pune, 1929; p.42.
8. SarthaYogaratnakar, Datto Ballala Borkar, translator, vol 2nd, SutikaRoga Chikitsa, chap- 44, Shri Gajanana Book Depo Prakashana, Pune, 1984; p.639.

9. Satyapalabhigacharya (editor), Kashyapa Samhita (VriddhaJeevaka), Khilasthana, chap-11, 4th ed. Chaukhambha Sanskrit Sansthan, Varanasi. 1994; p.305.

10. Charaka Samhita, of Agnivesha, revised by Charaka Acharya, Yadavaji Trikamaji Chaukhambha Orientalia, 5th edition, 2001; 348.

11. P.V. Sharma, Dravyaguna Vijnana, Vol.2, Chaukhambha Bharti Academy Varanasi, 2012,

12. Sutika Paricharya and Its Importance Sukeshini L. Patingrao, Salim S. Mulla Ayurlog: National Journal of Research in Ayurved Science- 2019; (7)(1): 1-9

13. sutikaParicharya and Its Importance Sukeshini L. Patingrao, Salim S. Mulla Ayurlog: National Journal of Research in Ayurved Science- 2019; (7)(1): 1-9

14. sutikaParicharya and Its Importance Sukeshini L. Patingrao, Salim S. Mulla Ayurlog: National Journal of Research in Ayurved Science- 2019; (7)(1): 1-9

15. Ibid Charaka Samhita, Sutra Sthana. 26(42-4):144. [Google Scholar]

16. Vol. 73. Varanasi: Chunekar Chaukhamba Bharati Academy; 2002. Bhavaprakasa Nighantu - Hindi Commentary by Dr. K. C. Haritakyadi Varga; p. 24. Reprint. [Google Scholar]

17. Dr. Santosh Kamble* 1, Dr. Prakash Mane2, Dr. Dahake S. J.3, Dr. Surekha Atram4, Dr. Amar Kamble5 and Dr. Prashant Khade COMPARATIVE STUDY OF SHRUNGATAK CHURNA AND VIDARIKAND CHURNA IN THE MAN-AGEMENT OF STANYAKSHAYA, WJPR, Volume 6, Issue 9, 193-199. Review Article ISSN 2277-7105

18. Nilesh Manohar Ingle, Nisha Kumari Ojha, Abhimanyu Kumar, Clinical study to evaluate the Brinhaniya effect of Vidari-kandadi Yog to enhance the sport performance in childrenJ Ayurveda Integr Med. 2013 Jul-Sep; 4(3): 171-175.

\section{Source of Support: Nil \\ Conflict of Interest: None Declared}

How to cite this URL: Komal Gurjar et al: Review Of Charakokta Sutika Paricharya And Its Clinical Significance. International Ayurvedic Medical Journal \{online\} 2021 \{cited September 2021\} Available from: http://www.iamj.in/posts/images/upload/2182_2190.pdf 